\title{
BILANS DEZINDUSTRIALIZACJI
}

ANDRZEJ KARPIŃSKI, STANISŁAW PARADYSZ,

PAWE SOROKA, WIESŁAW ŻÓkTKOWSKI.

JAK POWSTAWAKY I UPADAKY

ZAKŁADY PRZEMYSŁOWE W POLSCE

Karolina Mikołajewska

Akademia Leona Koźmińskiego/Uniwersytet Warszawski

Książka Jak powstawaty $i$ upadaty zakłady przemystowe w Polsce. Losy po 1989 roku zakładów zbudowanych w PRL wydana w 2013 roku przez wydawnictwo Muza podnosi tematykę ważną i z pewnością zbyt mało obecną w literaturze zarówno akademickiej, jak i popularnej, jaką jest bilans przemian przemysłu polskiego w związku z transformacją systemowa. Temat ten podjęło czterech autorów, wspartych przez licznych współpracowników w terenie, którzy uczestniczyli w gromadzeniu szczegółowych danych o zakładach przemysłowych. Andrzej Karpiński, emerytowany profesor ekonomii, w PRL przez 35 lat pracowal w centralnych organach planowania na stanowiskach kierowniczych. Stanisław Paradysz jest byłym wiceprezesem GUS. Paweł Soroka jest profesorem Uniwersytetu Jana Kochanowskiego w Kielcach i Warszawskiej Szkoły Zarządzania, a Wiesław Żółtkowski - menedżerem bankowym i właścicielem firmy doradczej. Takie zestawienie daje nam pewne wyobrażenie o perspektywie badawczej autorów: prezentują oni pracę makroekonomiczną czy makrosocjologiczna, która została oparta na licznych danych statystycznych zaczerpniętych z GUS i REGON. Nie skutkuje to jednak jej hermetycznościa: pozwala pokazać, że tezy, które w sposób systematyczny i logiczny składają się na publikację, zostały poparte szerokimi badaniami. Wydaje się, że wybór takiego stylu może przyczynić się do szerszego odbioru analizy, szczególnie że dotychczasowe badania poświęcone bilansowi dezindustrializacji Polski po 1989 roku raczej nie trafiały do głównego nurtu.

Obecnie jednak zbiegła się w czasie publikacja kilku prac, które być może przyczynią się do szerszego rozumienia procesów transformacji. Mam tu na myśli m.in. ostatnią książkę Adama Leszczyńskiego (2013), 
w której omawia on ideologie modernizacyjne krajów peryferyjnych, w tym Polski, w XX wieku i umożliwia ogląd dziejów polskich strategii wychodzenia z zapóźnienia gospodarczego na tle innych państw nowoczesnej gospodarki-świata. Podobną tematykę podejmuje w nowej monografii polityk modernizacyjnych w Polsce Wojciech Musiał (2013). Dalej warto zauważyć w tym kontekście także książkę Patologia transformacji autorstwa Witolda Kieżuna (2012), w której krytycznie analizowane jest wchodzenie do Polski międzynarodowego kapitału. Ta ostatnia praca wpisuje się w nurt dyskusji nad prywatyzacja reprezentowany m.in. przez Jacka Tittenbruna (2008), który w czterotomowej publikacji prezentuje mikroanalizę przebiegu prywatyzacji majątku państwowego, punktując działania poszczególnych aktorów, nie stroniąc od wskazywania ich nazwisk i odpowiedzialności za decyzje.

Praca Jak powstawaty $i$ upadaty zakłady przemystowe ma jednak inny wydźwięk niż monografia Tittenbruna. Po pierwsze, ze względu na metodę i poziom analizy, a po drugie, na cele pracy. Jak zostało już powiedziane, autorzy opierają się przede wszystkim na danych statystycznych dotyczących przemysłu w Polsce. Za cel stawiają sobie kompleksową ocenę wpływu reform zapoczątkowanych w 1989 roku na kondycję przemysłu polskiego, a dokładnie na potencjał przemysłowy kraju wybudowany od podstaw w PRL. Jednocześnie wielokrotnie podkreślają, że ich praca

nie jest w żadnym stopniu negacją dwudziestolecia III RP i nie może być utożsamiana z kwestionowaniem potrzeby wprowadzania zmian. Jest jedynie krytyczną analiza i ocena sposobu dokonywania tej przemiany. Jej jedyną intencja jest ukazanie skomplikowanej prawdy tamtych lat tylko po to, aby zwiększyć nasze szanse na sukces w przyszłości. (Karpiński et al. 2013: 16)

Liczne podobne zastrzeżenia wskazują na to, jak bardzo drażliwy temat podejmuja autorzy. Moim zdaniem jednak są one nadmierne i mogą skutkować umniejszaniem dorobku autorów. Punktem wyjścia jest konstatacja, że we wprowadzonych na nowo realiach gospodarki kapitalistycznej upadł lub zachował szczątkowa działalność co trzeci zakład przemysłowy wybudowany w PRL (s. 49), a zatrudnienie w przemyśle w ciagu ostatnich dwudziestu lat spadło o 45\%, co stanowi precedens na skalę europejską (s. 53).

Autorzy gorliwie zapewniaja jednocześnie, że nie sam upadek szeregu zakładów powinien być oceniany krytycznie, ale skala owych procesów (s. 10) i ich charakterystyka strukturalna: przekonująco dokumentują bowiem, że w wyniku transformacji zlikwidowano niemal wszystkie zakłady 
przemysłowe wysokich technologii, a nie tylko przestarzały w stosunku do rynków zachodnich zbyt rozwinięty przemysł ciężki nastawiony na eksploatację zasobów surowcowych, którego kryzys autorzy uważają za nieunikniony i naturalny.

Książka jest podzielona na cztery części. Po streszczeniu metod badania autorzy przechodzą do raportu, w którym analizują i oceniają rolę zakładów przemysłowych zbudowanych w PRL na tle całego potencjału przemysłowego kraju, jak również omawiają zasięg likwidacji tych zakładów. Czytelnik nieznający tej tematyki doceni, że w jednej publikacji zgromadzono tak wiele przejrzyście przedstawionych informacji - co pozwoli na własną ocenę licznych wypowiedzi polityków czy publicystów zbyt łatwo stwierdzających destrukcyjny wpływ okresu PRL na stan przemysłu polskiego. Dzięki przedstawieniu prostych, a pieczołowicie zebranych danych dowiadujemy się m.in., że połowa z dużych zakładów przemysłowych, które działały w roku 1988, została wybudowana po II wojnie światowej. Jednym z celów planowania przemysłowego było wyrównywanie społecznych dysproporcji między regionami. Przykładem tego sa statystyki udziału zakładów zbudowanych w PRL w ogólnym potencjale przemysłowym województw, w których wysokie wyniki miały tzw. Ziemie Odzyskane (s. 40-43).

Jednocześnie autorzy podkreślają że struktura branżowa przemysłu, w którego rozwój inwestowano szczególnie w latach 70., „,nie była dostosowana do struktury popytu rynku światowego" (s. 46). W szczególności należy tu zwrócić uwagę na nadmierny, zdaniem autorów, udział tradycyjnego przemysłu ciężkiego, niedostatecznie rozwinięty przemysł konsumpcyjny oraz zbyt niski stopień rozwoju przemysłów wysokiej techniki (s. 46). Wnioski te stanowią zarazem element rozważań w kolejnym rozdziale, w którym przedyskutowane są przyczyny wysokiego poziomu likwidacji zakładów przemysłowych po 1989 roku. Autorzy wyróżniaja „obiektywne” przyczyny upadku, których upatrują w zamkniętej strukturze gospodarki socjalistycznej, mającej tendencje do autarkii, oraz w mechanizmach rynkowych, powodujących, że upadłość firm jest zjawiskiem niemożliwym do wyeliminowania (s. 50). Do przyczyn obiektywnych zaliczają także zmiany technologiczne. Zauważaja, że dzięki wyróżnieniu tych przyczyn można wyjaśnić genezę upadku około jednej czwartej przedsiębiorstw państwowych, które nie przetrwały w nowym systemie gospodarczym. Zagadka wciąż pozostaje około 400-500 przypadków, w których oprócz przyczyn rynkowych kluczowa była rola czynników politycznych. Przykładowo spadek obrotów w handlu z Federacją Rosyjską był dużo większy niż w innych krajach, które przeszły transformację u progu lat 90. (s. 51-53). Jeśli 
chodzi o likwidację zakładów przemysłowych według struktury branżowej, szczególnie niepokojące jest, że przemysł elektroniczny i informatyczny to branże, które utraciły około trzech czwartych majątku i choć upadek tych branż jest także wyjaśniany przez odniesienie do spadku obrotów w handlu wschodnim, autorzy odnotowuja, że sytuacja Polski na tle innych krajów przechodzących transformację była wyjątkowa. Autorzy punktują straty zarówno w przemyśle konsumpcyjnym (odzieżowym, skórzanym), jak i stoczniowym, i zbrojeniowym, w które inwestowano intensywnie w dekadzie Gierka, a więc nie tak dawno przed przełomem 1989 roku.

Część druga książki kończy się analiza przyczyn wyjątkowo dużej skali upadku zakładów przemysłowych wybudowanych w Polsce Ludowej po 1989 roku i wpływu tego procesu na stan gospodarki kraju. Autorzy dopatrują się przyczyn kryzysu przemysłu przede wszystkim w przebiegu procesu transformacji: krytykują brak polityki przemysłowej (przywołując słowa ministra Tadeusza Syryjczyka, który stwierdzał, że „najlepsza polityka przemysłowa jest jej brak”), pośpiech w przeprowadzaniu reform, nieprzyjazny stosunek państwa do przemysłu, niewystępujący w innych krajach, błędy w procesie prywatyzacji (jednocześnie sama decyzja o prywatyzacji oceniana jest jako słuszna), w szczególności niezabezpieczenie terenów przemysłowych przed łatwym przekształceniem w tereny budowlane oraz enigmatycznie opisane dążenia jednostek i przedstawicieli zagranicznego kapitału do bogacenia się (s. 66-81).

W kolejnej części autorzy przedstawiają szczegółową dokumentację wyników badania. Omawiają strukturę przemysłu, analizując zarówno branże przemysłowe, jak i rozmieszczenie przestrzenne zakładów według województw. Na uwagę zasługuje m.in. analiza dynamiki zatrudnienia w przemyśle w poszczególnych województwach - dzięki prezentacji danych poparta jest teza o dążeniu PRL do niwelowania różnic między województwami.

W ostatniej zaś części autorzy podsumowują swoje prace badawcze i przedstawiaja wnioski z doświadczeń transformacji w przemyśle zarówno dla Polski, jak i dla innych krajów wstępujących na ścieżkę modernizacji. Twierdzą że można było zapobiec likwidacji przemysłu polskiego w tak wielkiej skali, gdyby istniała spójna polityka przemysłowa (i była w gestii ówczesnego Ministerstwa Przemysłu, a nie Ministerstwa Przekształceń Własnościowych); gdyby powstał fundusz państwowy na rzecz restrukturyzacji przedsiębiorstw zagrożonych bankructwem, których często nawet nie próbowano ratować; gdyby zmiany były rozciagnięte w czasie; gdyby wspierano popyt krajowy oraz wykorzystywano kapitał zagraniczny w służbie państwa (tzw. decoy policy) i gdyby zapewniono bardziej restrykcyjne 
przepisy prawne chroniące m.in. grunty przemysłowe oraz - wreszcie gdyby owych przepisów przestrzegano.

Ten krótki przegląd treści książki miał na celu wykazanie, że autorzy wykonali ogromna pracę (opierają się na danych dla 97,3\% zakładów przemysłowych stworzonych w PRL, które zatrudniały ponad 100 osób) i bez wątpienia ich publikacja stanowi cenne i poręczne źródło danych zarówno dla osób, które nie zajmują się tematyką transformacji lub historii gospodarki w Polsce, jak i dla tych, którzy prowadzą prace badawcze w tych dziedzinach. Autorzy w sposób spójny przedstawiają najważniejsze wyniki i dostarczają wielu ważnych informacji, które z pewnością pozwolą wzbogacić makroanalizy transformacji. Stąd w pracy rażą ciagłe zapewnienia, że intencją autorów było obiektywne przedstawienie danych i że „oczywiście żadna ze sformułowanych powyżej krytycznych uwag nie podważa ani nie przekreśla większości pozytywnych zmian w przemyśle [...] ani też sukcesu transformacji w zmianie ustroju" (s. 85).

Natomiast w stosunku do podrozdziałów prezentujących wyniki badań ilościowych fragmenty teoretyczne lub poświęcone wnioskom wydaja się niedopracowane. Po pierwsze, bibliografia książki liczy zaledwie kilka pozycji. W treści obficie zaś są cytowane tygodniki polskie, w szczególności „Angora” oraz brytyjski tygodnik „The Economist”, a właściwie jeden raport poświęcony polskiej gospodarce, który ukazał się w tym medium w 1993 roku. Tekst ten w zamyśle autorów miał zawierać esencję poglądów zachodnich neoliberałów na reformy w Polsce. Po drugie, w pracy jest wiele sformułowań, takich jak ,jak wykazały doświadczenia światowe, strategia przemysłowa jest szczególnie potrzebna krajom opóźnionym w rozwoju przemysłu” (s. 67), czy powołań na bliżej nieokreślonych „ekspertów” (s. 316), które pozostaja niedookreślone, co powoduje, że łatwo ich twierdzenia odrzucić. Opisując koncepcje z zakresu polityki gospodarczej, autorzy nie podsuwaja czytelnikowi żadnych dodatkowych źródeł, dzięki którym można by uzupełnić lekturę ich książki. Po trzecie, w nielicznych przypadkach, gdy podani są autorzy określonych koncepcji, dochodzi czasem do rażących błędów. Przykładem niech będzie „«terapia szokowa» w najbardziej radykalnej formie zalecan[a] przez J. Schumpetera, jaka zrealizowano w Polsce" (s. 318). Zmarly w latach 50. teoretyk ekonomii stworzył co najwyżej koncepcję „twórczej destrukcji”, w ramach której opisywał, jak innowacje technologiczne doprowadzaja do upadku przemysłów starszego typu (Schumpeter 2009), ale z pewnością nie był współtwórcą doktryny neoliberalnej.

Wreszcie można krytykować styl wypowiedzi autorów, którzy rzadko punktują, kto ponosi odpowiedzialność za decyzje polityczne, które 
doprowadziły do upadku całych gałęzi przemysłu. Być może jednak ten zabieg pozwolił na zachowanie klarowności wywodu i nie zbliżył ich do drobiazgowej analizy Tittenbruna, która wszak jest już dostępna na rynku książkowym. Szkoda jednak, że niektóre myśli autorów pozostaja niedokończone, interpretacje są urwane w połowie. W tym miejscu także dopatrywałabym się obawy autorów przed posądzeniem o całościowa krytykę przemian po 1989 roku. Na razie efektem jest świetna praca analityczna prezentująca liczne zagregowane dane, przedstawione w ciekawy i jasny sposób, które uzupełnione są połowicznymi analizami przyczyn o wątpliwej czasami wartości teoretycznej. W ten sposób istotny wniosek mówiący o doniosłej roli PRL w modernizacji Polski, nawet jeśli był to proces obciążony wieloma błędami strukturalnymi, może nie wybrzmieć z wystarczającą siłą, którą zapewniałoby samo przekonujące przedstawienie danych, którymi dysponują autorzy. Karpiński i inni wzywaja do kontynuowania badań, przyznając, że na objęcie analogicznym badaniem zakładów przemysłowych, które powstały przed II wojną światową i zostały znacjonalizowane, nie starczyło im środków (s. 317). Wskazują, że należy przeprowadzić analizę porównawczą z innymi krajami, które doświadczyły transformacji i z gospodarki centralnie planowanej przeszły do struktur wolnorynkowych. Podkreślają także konieczność przeprowadzenia case studies miast oraz pojedynczych zakładów przemysłowych. W przedstawionych przez nich propozycjach wyraźnie brakuje pomysłu przeprowadzenia analogicznej analizy dla zakładów sprywatyzowanych oraz tych, które pozostały w rękach państwowych. Być może jednak takie badanie wciąż stanowi dla autorów temat zbyt kontrowersyjny.

Bibliografia:

/// Karpiński A., Paradysz S., Soroka P., Żółtkowski W. 2013. Jak powstawaty $i$ upadaly zaktady przemystowe w Polsce. Losy po 1989 roku, Muza S.A., Warszawa.

/// Kieżun W. 2012. Patologia transformacji, Poltext, Warszawa.

/// Leszczyński A. 2013. Skok w nowoczesnośc. Polityka wrrostu w krajach peryferyjnych 1943-1980,Wydawnictwo Krytyki Politycznej, Warszawa.

/// Musiał W. 2013. Modernizacja Polski, Wydawnictwo UMK, Toruń.

/// Schumpeter J. 2009. Kapitalizm, socjalizm, demokracja, tłum. M. Rusiński, Wydawnictwo Naukowe PWN, Warszawa.

/// Tittenbrun J. 2007. Z deszczu pod rynne. Meandry polskiej prywatyzacji t. 1-4, Wydawnictwo Zysk i S-ka, Poznań. 